\title{
Evaluation of TNFRSF11B Gene Polymorphism in Patients with Acute Stroke
}

\author{
Pınar Çoğaş ${ }^{l}$, Nevin Karakuş ${ }^{1}$, Nurşah Başol ${ }^{2}$, Serbülent Yiğit ${ }^{1}$
}

\begin{abstract}
Objective: Tumor necrosis factor receptor superfamily, member 11b (TNFRSF11B) has been suggested to be a risk factor for atherosclerosis and cardiovascular diseases because of the observation of osteoporosis and vascular diseases together in human, and the high levels of serum TNFRSF11B in these patients in clinical trials. In this study, we aimed to investigate the association between TNFRSF11B gene $1181 \mathrm{G}>\mathrm{C}$ polymorphism and acute stroke as a cerebrovascular disease.
\end{abstract}

Methods: In this study, the DNAs of 107 acute stroke patients and 100 healthy controls have been analyzed by polymerase chain reaction (PCR) and restriction fragment length polymorphism (RFLP). Statistical analyses were performed by using chi-square and analysis of variance tests.

Results: When we compared the genotype and allele frequencies of patients and controls, any statistically significant differences was not found between them $(p=0.476$ and $p=0.622$, respectively). Any association also was not observed when demographical and clinical characteristics of patients was compared with TNFRSF11B gene 1181G>C polymorphism ( $p>0.05)$.

Conclusion: As a result, our findings showed that there was no association between TNFRSF11B gene 1181G>C polymorphism and acute stroke. However, further studies can reveal more clearly whether there is a relationship between TNFRSF11B gene polymorphism and acute stroke in Turkish population.

Key words: TNFRSF11B, acute stroke, polymorphism. J Clin Exp Invest 2016; 7 (2): 184-189

\section{Akut İnme’li Hastalarda TNFRSF11B Gen Polimorfizminin Değerlendirilmesi}

\section{ÖZET}

Amaç: İnsanda osteoporoz ve vasküler hastalıkların birlikte gözlenmesi ve yapılan klinik çalışmalarda bu hastalarda serum tümör nekrozis faktör reseptör süper ailesi üyesi 11b (TNFRSF11B) düzeylerinin yüksek bulunmasından dolayı, TNFRSF11B'nin ateroskleroz ve kardiyovasküler hastalıklar için risk faktörü olabileceği öne sürülmüştür. Bu çalışmada, serebrovasküler bir hastalık olan akut inme ile TNFRSF11 geni 1181G > C polimorfizmi arasındaki ilişkiyi araştırmayı amaçladık.

Yöntemler: Çalışmamızda 107 akut inme geçirmiş hasta ve 100 sağlıklı kontrol DNA'ları polimeraz zincir reaksiyonu (PCR) ve restriksiyon fragment uzunluk polimorfizmiyle (RFLP) analiz edildi. İstatistiksel analiz ki-kare ve varyans analizi kullanılarak yapıldı.

Bulgular: Hasta ve kontrollerin genotip ve allel sıklıkları karşılaştırıldığında aralarında istatistiksel olarak anlamlı bir fark bulunmadı (sırasıyla, $p=0.476$ ve $p=0.622$ ). Akut inme geçirmiş hastaların demografik ve klinik özellikleri ile TNFRSF11B geni 1181G >C polimorfizmi karşılaştırıldığında da herhangi bir ilişkiye rastlanmadı $(p>0.05)$.

Sonuç: Bulgularımız, akut inme ile TNFRSF11B geni 1181G >C polimorfizmi arasında bir ilişki olmadığını göstermektedir. Bununla birlikte Türk popülasyonunda bu daha sonraki çalışmalarla akut inme ile TNFRSF11B gen polimorfizmi arasındaki bir ilişki olup olmadığı daha net ortaya konabilir.

Anahtar kelimeler: TNFRSF11B, akut inme, polimorfizm

\footnotetext{
${ }^{1}$ Gaziosmanpaşa Üniversitesi, Tıp Fakültesi, Tıbbi Biyoloji Anabilim Dalı Tokat, Turkey

${ }^{2}$ Gaziosmanpaşa Üniversitesi, Tıp Fakültesi, Acil Tıp Anabilim Dalı Tokat, Turkey
}

Correspondence: Nevin Karakuş,

Gaziosmanpaşa Üniversitesi, Tıp Fakültesi, Tıbbi Biyoloji Anabilim Dalı, 60100, Tokat, Turkey Email: nevinbalci@hotmail.com

Received: 20.04.2016, Accepted: 15.05.2016

Copyright (C) JCEI / Journal of Clinical and Experimental Investigations 2016, All rights reserved 


\section{INTRODUCTION}

Stroke is defined as sudden developing, abnormal contractions, muscle weakness and speech disorders, and is caused by blockage or rupture of blood vessels that are providing blood flow to a certain area of the brain [1]. According to a report of the World Health Organization published in 2008, stroke and other cerebrovascular diseases are the 2 nd cause of death after coronary heart disease in the world [2]. The most common three causes of ischemic stroke, constituting $80-85 \%$ of acute stroke, are atherothrombosis, arterial embolism and reduction in blood supply [3]. The most common known risk factors for stroke are hypertension, diabetes mellitus and high cholesterol [4].

Tumor necrosis factor receptor superfamily member 11B (TNFRSF11B) is a secretory glycoprotein. It is also called as osteoprotegerin (OPG), when the serum level of it is examined. It is built on human chromosome 8 (8q24). It contains 5 exons, 4 introns and is $29 \mathrm{~kb}$ in length. Unlike other members of the tumor necrosis factor receptor family, it does not include transmembrane and cytoplasmic domains [5]. TNFRSF11B expressed in many immune cells such as brain, liver, spleen, kidney and bone marrow [6]. Its main function is the inhibition of osteoclast differentiation and activation [5].

Receptor activator nuclear kappa B (RANK), a heterotrimeric protein, is a member of tumor necrosis factor receptor superfamily, and controls the calcium metabolism and osteoclastogenesis. RANK is defined as to be expressed in breast tissue, epithelial cells, chondrocytes, B and T lymphocytes, and the surfaces of precursor and mature osteoclasts [7-9]. The RANK ligand (RANKL), a homotrimetric protein known as TNFRSF11B ligand or osteoclast differentiation factor receptor, is expressed by endothelial cells, activated $\mathrm{T}$ cells, osteoclasts and chondrocytes [10,11]. RANKL increases bone resorption and loss by inhibiting osteoclast formation $[6,12]$.

The definite risk factors for stroke include hypertension, diabetes mellitus, heart disease, hyperlipidemia, and smoking. According to results of a study, in women with osteoporosis with a large number of cardiovascular risk factors, serum TNFRSF11B levels was found to be positively correlated with systemic vascular resistance, however negatively correlated with large artery elasticity index [13]. One of the polymorphisms identified in TNFRSF11B gene is the missense $1181 \mathrm{G}>\mathrm{C}$ polymorphism that change lysine amino acid to asparagine $(\mathrm{K} 3 \mathrm{~N})$ in the $3^{\text {' }}$ amino terminus in the TNFRSF11B signal region, which may lead to alterations in protein activity $[14,15]$.

In the study that was carried out in an Italian population among diabetic patients who have had no stroke and diabetic patients who have had a stroke, the relationship between TNFRSF11B gene $245 \mathrm{~T}>\mathrm{G}$, 950T $>\mathrm{C}$ and $1181 \mathrm{G}>\mathrm{C}$ polymorphisms and stroke disease were examined and a relationship was found between TNFRSF11B gene polymorphisms and ischemic stroke [16]. Genetic studies are essential for stoke as are for many other diseases to determine the etiology of the disease and the patients with potential risk. In this study; we aimed to evaluate the association between acute stroke and TNFRSF11B gene $1181 \mathrm{G}>\mathrm{C}$ polymorphism in Turkish population.

\section{METHODS}

\section{Study Population}

One hundred and seven patients (68 male and $39 \mathrm{fe}-$ male; mean age: $67.10 \pm 12.83$ years), applied to Emergency Medical Service of Gaziosmanpasa University and laid acute ischemic stroke diagnosis and a total of 100 healthy controls (51 male and 49 female; mean age: $64.08 \pm 9.41$ years) with no history of acute stroke in himself or his family, were enrolled in this study. Gender and age range of healthy controls were compatible with patients. For this study, the approval was received from the ethics committee of the Scientific Research Evaluation Commission of Gaziosmanpasa University, Faculty of Medicine, in August 1, 2014 (Approval number: 14-KAEK-179). Written permissions were received from the individuals in the patient and control groups that they could be enrolled in the study.

\section{Genotype Analyses}

Five ml blood was drawn to EDTA tubes from individuals of study population. DNA isolation from blood was made by the method of commercially available DNA isolation kit. The isolated DNA was stored at $-20^{\circ} \mathrm{C}$. Determination of TNFRSF11B gene $1181 \mathrm{G}>\mathrm{C}$ polymorphism (rs2073618) was made by polymerase chain reaction (PCR) and restriction fragment length polymorphism (RFLP) methods. PCR was made by using F: 5' - GTT TCC GGG GAC CAC AAT GAA CTA - $3^{\prime}$ and R: 5' - TAG GGG AAG CAT GGC ATA ACT TGA -3' primers [17]. PCR program was as follows: Initial denaturation at $94^{\circ} \mathrm{C} 4 \mathrm{~min}$, denaturation 
at $94^{\circ} \mathrm{C} 45 \mathrm{sec}$, hibridization at $62^{\circ} \mathrm{C} 40 \mathrm{sec}$, extension at $72^{\circ} \mathrm{C} 45 \mathrm{sec}$, final extension at $72^{\circ} \mathrm{C} 5 \mathrm{~min}$ and number of cycles was $30.220 \mathrm{bp}$ PCR products were obtained from the region that amplified. For restriction enzyme digestion analyses of the TNFRSF11B gene $1181 \mathrm{G}>\mathrm{C}$ polymorphism, PCR products, containing the polymorphic point, were digested in a $15 \mu \mathrm{l}$ restriction enzyme mixture including 1,5 $\mu$ l Fast Digest Green Buffer $(10 \times), 0,3 \mu$ l SpeI enzyme $(10 \mathrm{u} / \mu \mathrm{l}), 3,2$ $\mu \mathrm{l} \mathrm{dH} 2 \mathrm{O}, 10 \mu \mathrm{l}$ PCR product. $1181 \mathrm{G}>\mathrm{C}$ polymorphism was evaluated after the PCR products allowed to cut with the restriction enzyme SpeI at $37^{\circ} \mathrm{C}$ for 2 hours. While the $\mathrm{G}$ allele being uncut with restriction enzyme, the $\mathrm{C}$ allele was divided into two parts as 196 bp and 24 bp in length (Figure 1).

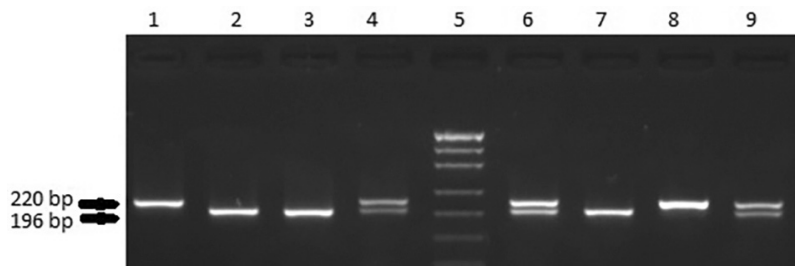

Figure 1. The RFPL results of TNFRSF11B gene $1181 \mathrm{G}>\mathrm{C}$ polymorphic region determined by Spel restriction endonuclease. Lines 1 and 8: homozygous dominant (GG); lines 2, 3 and 7: homozygous recessive (CC); lines 4, 6 and 9 heterozygous (GC). 5: pUC19 DNA/Mspl (Hpall) Marker

\section{Statistical Analysis}

Statistical Package Program (SPSS) version 20.0 and Openepi 3.01 (www.openepi.com) software programs were used to determine statistical analysis. Results were given as mean $( \pm)$ and standard deviation. The relation of $1181 \mathrm{G}>\mathrm{C}$ polymorphism with clinical and demographic characteristics were analyzed by using chi-square, Fisher's exact or analysis of variance (ANOVA) tests. Odds ratio (OR) and 95\% Confidence Interval (CI) were used for ascertaining risk factors. All $p$ values were two-tailed and $p$-value less than 0.05 were considered statistically significant. For detected genotype frequencies on whether a deviation from Hardy-Weinberg equilibrium was available was determined by chi-square test.

\section{RESULTS}

In this study, to determine the relationship between TNFRSF11B gene $1181 \mathrm{G}>\mathrm{C}$ polymorphism and acute stroke, DNAs of 107 acute stroke patients and 100 healthy controls were examined. Acute stroke patients applied to Gaziosmanpasa University, Faculty of Medicine, Department of Emergency Medicine from Tokat and around were included to this study regardless if the disease is familial and not. The age and gender of the patient and control groups was observed to be compatible with each other (Table 1).

Table 1. Statistical findings of gender and mean age of the individuals in the acute stroke patients and the control group included in the study

\begin{tabular}{|c|c|c|c|}
\hline & $\begin{array}{c}\text { Acute Stroke } \\
\text { Patients }(n=107)\end{array}$ & $\begin{array}{l}\text { Control Group } \\
(n=100)\end{array}$ & $p$ value \\
\hline \multicolumn{4}{|c|}{ Gender, n (\%) } \\
\hline Female & $39(36.4)$ & 49 (49.0) & \multirow{2}{*}{0.056} \\
\hline Male & $68(63.6)$ & $51(51.0)$ & \\
\hline Age, years & $67.10 \pm 12.83$ & $64.08 \pm 9.41$ & 0.092 \\
\hline
\end{tabular}

When we compared the genotype and allele frequencies of patients and controls, no statistical differences were observed between them $(p=0.476$, $\mathrm{p}=0.622$, respectively). When we compare genotypes of patients and controls in the form of $\mathrm{GG}+\mathrm{GC}$ against $\mathrm{CC}$ and $\mathrm{GG}$ against $\mathrm{GC}+\mathrm{CC}$, it did not make any statistical difference, either $(p=0.909, p=0.622$, respectively) (Table 2).

Demographical and clinical characteristics of acute stroke patients involved in this study, evaluated according to TNFRSF11B gene $1181 \mathrm{G}>\mathrm{C}$ polymorphism was given in Table 3. According to results of chi-square and variance analysis, any statistically significant correlation between data of age, systolic blood pressure, diastolic blood pressure, body temperature, respiratory rate, gender, presence of hypertension and diabetes mellitus, chronic kidney and heart failure, mental status, ECG results, and the presence of neurological findings of patients and TNFRSF11B gene $1181 \mathrm{G}>\mathrm{C}$ polymorphism was not shown (Table $3)$. But, although it is not statistically significant, CC genotype frequency of acute stroke patients with neurological findings was half of the acute stroke patients without neurological findings ( $55.0 \%$ vs. $26.8 \%)$. Also we observed that the number of the male patients over the age of 55 was higher compared to the number of female patients. Genotype distributions of patient group and control group were consistent with the Hardy-Weinberg equilibrium. 
Table 2. The genotype and allele distributions for TNFRSF11B gene $1181 \mathrm{G}>\mathrm{C}$ polymorphism of acute stroke patients and the control group

\begin{tabular}{|c|c|c|c|c|}
\hline & Acute Stroke Patients ( $n=107)$ n (\%) & Control Group ( $n=100)$ n (\%) & $\mathbf{p}$ & OR (95\%Cl) \\
\hline \multicolumn{5}{|l|}{ Genotypes } \\
\hline GG & $15(14.0)$ & $20(20.0)$ & \multirow{3}{*}{0.476} & \\
\hline GC & $58(54.2)$ & $48(48.0)$ & & \\
\hline $\mathrm{CC}$ & $34(31.8)$ & $32(32.0)$ & & \\
\hline $\mathrm{GG}+\mathrm{GC}: \mathrm{CC}$ & $73(68.2): 34(31.8)$ & $68(68.0): 32(32.0)$ & 0.909 & $0.99(0.55-1.78)$ \\
\hline $\mathrm{GG}: \mathrm{GC}+\mathrm{CC}$ & $15(14.0): 92(86.0)$ & $20(20.0): 80(80.0)$ & 0.336 & $1.53(0.73-3.24)$ \\
\hline \multicolumn{3}{|l|}{ Alleles } & \multirow{3}{*}{0.622} & \multirow{3}{*}{$1.12(0.76-1.66)$} \\
\hline G & $88(41.1)$ & $88(44.0)$ & & \\
\hline C & $126(58.9)$ & $112(56.0)$ & & \\
\hline
\end{tabular}

TNFRSF11B: Tumor necrosis factor receptor superfamily, member $11 \mathrm{~b}$. Data were analyzed by $\chi 2$ test.

Table 3. Demographic and clinical characteristics of the acute stroke patients included in study evaluated according to TNFRSF11B gene $1181 \mathrm{G}>$ C polymorphism

\begin{tabular}{|c|c|c|c|c|c|}
\hline \multirow[b]{2}{*}{ Characteristics } & \multirow[b]{2}{*}{ Total } & \multicolumn{4}{|c|}{ TNFRSF11B 1181G>C } \\
\hline & & GG & GC & $\mathrm{CC}$ & $\mathbf{p}$ \\
\hline Age (year) & $67.10 \pm 12.833$ & $65.53 \pm 13.917$ & $68.02 \pm 13.640$ & $66.24 \pm 11.048$ & 0.718 \\
\hline Systolic blood pressure $(\mathrm{mmHg})$ & $144.11 \pm 26.797$ & $143.33 \pm 20.151$ & $141.73 \pm 26.325$ & $148.39 \pm 29.899$ & 0.551 \\
\hline Diastolic blood pressure $(\mathrm{mmHg})$ & $85.55 \pm 13.065$ & $89.17 \pm 9.962$ & $84.17 \pm 12.958$ & $86.45 \pm 14.271$ & 0.444 \\
\hline Body temperature $\left({ }^{\circ} \mathrm{C}\right)$ & $36.40 \pm 0.373$ & $36.32 \pm 0.311$ & $36.42 \pm 0.367$ & $36.42 \pm 0.414$ & 0.736 \\
\hline Respirarory rate (breaths per min) & $20.65 \pm 4.125$ & $21.36 \pm 3.075$ & $20.45 \pm 4.968$ & $20.55 \pm 3.419$ & 0.819 \\
\hline \multicolumn{5}{|l|}{ Gender } & \multirow{3}{*}{0.826} \\
\hline Female & $39(36.4)$ & $6(40.0)$ & $22(37.6)$ & $11(32.4)$ & \\
\hline Male & $68(63.6)$ & $9(60.0)$ & $36(62.1)$ & $23(67.6)$ & \\
\hline \multicolumn{5}{|l|}{ Hypertension, $\mathrm{n}(\%)$} & \multirow{3}{*}{0.274} \\
\hline Yes & 66 (75.9) & $8(72.7)$ & $38(82.6)$ & $20(66.7)$ & \\
\hline No & $21(24.1)$ & $3(27.3)$ & $8(17.4)$ & $10(33.3)$ & \\
\hline Diabetes mellitus, n (\%) & & & & & 0.541 \\
\hline Yes & $32(37.6)$ & $4(36.4)$ & $20(42.6)$ & $8(29.6)$ & \\
\hline No & $53(62.4)$ & $7(63.6)$ & $27(57.4)$ & $19(70.4)$ & \\
\hline Chronic renal failure, $\mathrm{n}(\%)$ & & & & & 0.796 \\
\hline Yes & $3(3.8)$ & 0 & $2(4.4)$ & $1(4.2)$ & \\
\hline No & $76(96.2)$ & $10(100)$ & $43(95.6)$ & $23(95.8)$ & \\
\hline Chronic cardiac failure, $\mathrm{n}(\%)$ & & & & & 0.612 \\
\hline Yes & $15(18.8)$ & $1(10.0)$ & $10(22.2)$ & $4(16.0)$ & \\
\hline No & $65(81.3)$ & $9(90.0)$ & $35(77.8)$ & $21(84.0)$ & \\
\hline Mental status, $\mathrm{n}(\%)$ & & & & & 0.374 \\
\hline Normal & $72(75.0)$ & $11(84.6)$ & $35(70.0)$ & $26(78.8)$ & \\
\hline Confusion & $17(17.7)$ & 0 & $11(22.0)$ & $6(18.2)$ & \\
\hline Stupor & $3(3.1)$ & $1(7.7)$ & $1(2.0)$ & $1(3.0)$ & \\
\hline Coma & $4(4.2)$ & $1(7.7)$ & $3(6.0)$ & 0 & \\
\hline ECG results, $\mathrm{n}(\%)$ & & & & & 0.625 \\
\hline Normal & $51(51.5)$ & $8(61.5)$ & $27(50.0)$ & $16(50.0)$ & \\
\hline $\mathrm{AF}$ & $35(35.4)$ & $4(30.8)$ & $21(38.9)$ & $10(31.3)$ & \\
\hline ST abnormalities & $5(5.1)$ & $1(7.7)$ & $1(1.9)$ & $3(9.4)$ & \\
\hline Other & $8(8.1)$ & 0 & $5(9.3)$ & $3(9.4)$ & \\
\hline Neurological findings, $\mathrm{n}(\%)$ & & & & & 0.054 \\
\hline Yes & $82(80.4)$ & $12(14.6)$ & $48(58.5)$ & $22(26.8)$ & \\
\hline No & $20(19.6)$ & $2(10.0)$ & $7(35.0)$ & $11(55.0)$ & \\
\hline
\end{tabular}

Data were analyzed by analysis of variance or $\chi 2$ test. Mean plus standard deviation values are presented for age, systolic blood pressure, diastolic blood pressure, body temperature and respiratory rate. AF: Atrial fibrillation; ECG: Electrocardiography; TNFRSF11B: Tumor necrosis factor receptor superfamily, member $11 \mathrm{~b}$. 


\section{DISCUSSION}

The discovery and determination of the roles of RANK and RANKL, members of tumor necrosis factor receptor family, have helped in learning of the structure of bone biology. In studies with mice, it was shown that vascular calcification in aorta and renal artery as well as osteoporosis was seen in TNFRSF11B deficient mice. In recent studies related to TNFRSF11B gene, when the target vascular cells and the source osteoclasts of the TNFRSF11B gene considered together, a paracrine connection was exist between vascular and skeleton systems and increased serum TNFRSF11B levels has been suggested as an independent risk factor for progressive atherosclerosis and cardiovascular diseases. Soufi et al. has been found that $1181 \mathrm{G}>\mathrm{C}$ polymorphism in the first exon of the TNFRSF11B gene was related to cardiovascular diseases [18]. TNFRSF11B gene $1181 \mathrm{G}>\mathrm{C}$ polymorphism is a missense polymorphism that change lysine amino acid to asparagine $(\mathrm{K} 3 \mathrm{~N})$ in the $3^{6}$ amino terminus in the $\mathrm{TN}$ FRSF11B signal region, which may lead to alterations in protein activity $[14,15]$.

Stroke is generally known as a disease of the elderly population, and one of the major risk factors of stroke is age. The incidence of stroke doubles after the age of 55 and age is known among the non-modifiable risk factors. From 107 stroke patients that we conducted in this study, $68(63.6 \%)$ were male patients and $39(36.4 \%)$ were female patients. The average age of stroke patients was 67 . Men, over the age of 55, are known to capture to stroke more often compared to women. In our study, we observed that the number of the male patients over the age of 55 was higher compared to the number of female patients.

In an Italian population, a study was conducted among 364 diabetic patients with stroke and 492 diabetic patients without stroke [16]. In this study of Italian population, relationship between stroke disease and TNFRSF11B gene 245T $>$ G, 950T $>C$ 1181G $>C$ polymorphisms were analyzed. Looking at the data of TNFRSF11B gene $118 \mathrm{G}>\mathrm{C}$ polymorphism in this study of Italian population: Genotype frequencies of both the diabetic and stroke patients with the mean age of 72, 96 (26.4\%) people was CC, 188 (51.6\%) people was GC, $80(22.0 \%)$ people was GG; genotype frequencies of the diabetic patient without stroke with the mean age of $71,57(11.6 \%)$ people was $\mathrm{CC}$, 196 (39.8\%) people was GC, 239 (48.6\%) people was GG. As a result, ischemic stroke was found to be as- sociated with TNFRSF11B gene $1181 \mathrm{G}>\mathrm{C}$ polymorphism $(\mathrm{p}<0.0001)$. Also, this polymorphism has been suggested to be a marker for cerebrovascular diseases [19]. In our study, we examined acute stroke patients with mean age of the 67 and controls with mean age of 64. In the current study, we didn't find any statistically significant relationship between acute stroke and TNFRSF11B gene $1181 \mathrm{G}>\mathrm{C}$ polymorphisms, after the examination of DNAs of 107 acute stroke patients and 100 controls by RFLP analysis and statistical evaluation. Both in the study of the Italian population and in the study that we have done, GG genotype frequency was observed more often than GC and CC genotype frequencies. However, while there was a statistically significant relationship between TNFRSF11B gene $1181 \mathrm{G}>\mathrm{C}$ polymorphism and stroke in the study of Italian population, any statistically significant association was not found in our study.

In another study made in Italy, TNFRSF11B gene $245 \mathrm{~T}>\mathrm{G}, 950 \mathrm{~T}>\mathrm{C}$ and $1181 \mathrm{G}>\mathrm{C}$ polymorphisms were investigated in 177 patients with Carotid atherosclerosis disease and 303 control groups [20]. According to the results of this study of Italian population, in the patient group $\mathrm{CC}$ genotype was observed in 36 people (20.3\%), GC genotype in 75 people (42.4\%), GG genotype in 66 people (37.3), while in the control group CC genotype was observed in 33 people (10.9\%), GC genotype in 122 people $(40.3 \%)$, GG genotype in 148 people $(48.8 \%)$. In this study of Italian population, it was shown that men were more prone to this disease than women, and there was a statistically significant relationship between TNFRSF11B gene $1181 \mathrm{G}>\mathrm{C}$ polymorphism and hypertension, diabetes mellitus, coronary artery disease, ischemic stroke and peripheral arterial occlusive disease [20]. As a result, it was highlighted that TNFRSF11B gene and its genotype variants as being independent risk factor, can contribute to the pathogenesis of carotid atherosclerosis. Carotid atherosclerosis is known to cause stroke and the patient's age, hypertension, diabetes mellitus, coronary artery disease are also among the risk factors for stroke. In the current study, any association was not observed between TNFRSF11B gene 1181G $>$ C polymorphism and acute stroke. This may be due to multiple vascular roles of TNFRSF11B gene.

In conclusion, our study is the first study, which investigated the relationship between TNFRSF11B gene $1181 \mathrm{G}>\mathrm{C}$ polymorphism and acute stroke in Turkish population. According to findings obtained from this study, any significant relationship was not 
observed between TNFRSF11B gene $1181 \mathrm{G}>\mathrm{C}$ polymorphism and acute stroke.

\section{Acknowledgments}

This study was supported by the Gaziosmanpasa University Research Fund (Project No: 2014/104) and is a report of Master of Science thesis.

Declaration of Conflicting Interests: The authors declare that they have no conflict of interest.

Financial Disclosure: No financial support was received.

\section{REFERENCES}

1. Allan H, Ropper RHB. Adams and Victor's Principles of Neurology, $8^{\text {th }}$ edn. New York: McGraw-Hill, 2005:660.

2. Rosamond W, Flegal K, Furie K, et al. Heart disease and stroke statistics-2008 update: a report from the American Heart Association Statistics Committee and Stroke Statistics Subcommittee. Circulation. 2008;117:e25-146.

3. Ayala C, Croft JB, Greenlund KJ, et al. Sex differences in US mortality rates for stroke and stroke subtypes by race/ ethnicity and age,1995-1998. Stroke. 2002;33:1197- 1201.

4. Adams RD, Victor M. Ropper AH. Principles of Neurology, $6^{\text {th }}$ edn. USA: Mc Graw Hill,1997:777-873.

5. Schoppet M, Preissner KT, Hofbauer LC. RANK ligand and osteoprotegerin: paracrine regulators of bone metabolism and vascular function. Arterioscler Thromb Vasc Biol. 2002;22:549.

6. Brendan FB, Lianping X. Biology of RANK, RANKL and osteoprotogerin. Arthritis Research \&Therapy. 2007;9:1-7.

7. Fata JE, Kong YY, Li J, et al. The Osteoclast differentiation factor osteoprotegerin-ligand is essential for mammary gland development. Cell. 2000;103:41-50.

8. Kim NS, Kim HJ, Koo BK, et al. Receptor activator of NF kapa $\mathrm{B}$ ligand regulates the proliferation of mammary epithelial cells via Id2. Mol Cell Biol. 2006;26:1002-13.

9. Chen G, Sircar K, Aprikian A, et al. Expression of RANK L/RANK/OPG in primary and metastatic human prostate cancer as markers of disease stage and functional regulation. Cancer. 2006;107:289-98.

10. Suda T. Modulation of osteoclast differentiation and function by the new members of the tumor necrosis factor receptor and ligand families. Endocr Rev. 1999;20:345-57.

11. Kong YY. OPGL is a key regulator of osteoclastogenesis, lymphocyte development and lymph-node organogenesis. Nature. 1999;397:315-323.

12. Blair JM, Zheng Y, Dunstan CR. RANK ligand. Int J Biochem Cell Biol. 2007;39:1077-81.

13. Luckish A, Cernes R, Boaz M, et al. Effect of long-term treatment with risedronate on arterial compliance in osteoporotic patient with cardiovascular risk factors. Bone. 2008;43:279-283

14. Rumianowska A, Nehring P, Mrozikiewicz-Rakowska B, et al. Osteoprotegerin - a new marker of the atherosclerosis helpful in selecting patients at amputation risk? Leczenie Ran. 2011;8:1-5.

15. Jeffcoate WJ, Rasmussen LM, Hofbauer LC, Game FL. Medial arteria calcification in diabetes and its relationship to neuropathy. Diabetologia 2009;52:2478-88.

16. Biscetti F, Straface G, Giovannini S, et al. Association between TNFRSF11B gene polymorphisms and history of ischemic stroke in Italian diabetic patients. Human Genet 2013;132:49-55.

17. Seremak-Mrozikiewicz A, Barlik M, Drews K, et al. The genetic variants of RANKL/RANK/OPG signal trial in postmenopausal women with osteopenia and osteoporosis. Arch Perinat Med. 2011;17:72-80.

18. Soufi M, SchoppetM, Sattler A, et al. Osteoprotegerin gene polymorphisms in men with coronary artery disease. J Clin Endocrinol Metab. 2004;89:3764-8.

19. Mrozikiewicz A, Barlık M, Drews K, et al. The genetic variants of RANKL $\backslash$ RANK $\backslash O P G$ signal trial in postmenopausal women with ostepenia and osteoporosis. Arch Perinat Med. 2011;17:72-8.

20. Straface G, Biscetti F, Pitoco D, et al. Assessment of the genetic effects of polymorphism in the osteoprotegerin gene,TNFRSF11B, on serum osteoprotegerin levels and carotid plaque vulnerability. Stroke. 2011;24:3022-8. 